\title{
Ligninolytic enzymes production by Dichostereum sordulentum cultures in the presence of Eucalyptus bark as a natural laccase stimulator
}

${ }^{*}$ Emiliana Botto ${ }^{1}$, Alessandro D'Annibale ${ }^{2}$, Maurizio Petruccioli ${ }^{2}$, Alejandra Galetta $^{1}$, Sebastian Martínez ${ }^{3}$, Lina Bettucci ${ }^{4}$, Maria del Pilar Menéndez ${ }^{1}$

${ }^{1}$ Laboratorio de Biocatálisis y Biotransformaciones, Facultad de Química, Universidad de la República (UdelaR), General Flores 2124, 11800, Montevideo, Uruguay

2 Dipartimento per l'innovazione nei sistemi Biologici,

Agroalimentari e Forestali - Università degli Studi della Tuscia - Via San Camillo de Lellis snc Viterbo 01100 Italia

${ }^{3}$ Laboratorio de Patología Vegetal - INIA Treinta y Tres, Ruta 8, Km 281, 33000 Treinta y Tres, Uruguay

${ }^{4}$ Laboratorio de Micología - Facultad de Ciencias - Facultad de Ingeniería, UdelaR,

\section{ABSTRACT} Julio Herrera y Reissig 565, 11300, Montevideo, Uruguay

A strain of a fungal species, i.e., Dichostereum sordulentum, not yet isolated from either Uruguay or decayed Eucalyptus spp. wood, was investigated for its ability of producing extracellular ligninolytic enzymes. To this aim, the strain was grown on a N-rich liquid medium added with either bark or wood Eucalyptus dunnii sawdust. The former additive was more effective than the latter instimulating laccase leading to a production of $4.78 \mathrm{IU} \mathrm{mL} \mathrm{L}^{-1}$ which was further enhanced by the concomitant presence of $80 \mathrm{ppm} \mathrm{CuSO}_{4}\left(6.56 \mathrm{IU} \mathrm{mL}^{-1}\right)$. The two order of magnitude higher proanthocyanidin content in bark than in wood suggests that this fraction might be responsible for the higher stimulatory effect of the former on laccase production.

\section{Indexing terms/Keywords}

Bark; Dichostereum sordulentum; Eucalyptus;lacasse; ligninolytic enzymes.

\section{Academic Discipline And Sub-Disciplines}

Biotechnology

\section{SUBJECT CLASSIFICATION}

Enzyme production

\section{TYPE (METHODIAPPROACH)}

\section{Experimental}

\section{Council for Innovative Research}

Peer Review Research Publishing System

\section{Journal: JOURNAL OF ADVANCES IN BIOTECHNOLOGY}

Vol .5, No.1

www.cirjbt.org , jbteditor@gmail.com 


\section{INTRODUCTION}

In Uruguay, the forestry industry has grown in the last 20 years. Recently planted area has reached 1.812 .000 ha, and the zone destined for Eucalyptus plantation raised 694.000 ha in 2012 [1].

Eucalyptus wood is used to produce cellulose pulp and significant amounts of bark are generated as byproducts. Eucalyptus bark composition is well known to be rich in extractives. In recent years, lipophilic fractions have been shown to contain triterpenic acids [2] and around twenty phenolic compounds were identified from methanolic extracts of different Eucalyptus species [3].

In nature, lignin is efficiently decomposed by Basidiomycetes belonging to the ecological group of white-rot fungi. Due to the structural complexity of lignin and its random phenylpropanoic polymeric structure, enzymes involved in its degradation rely on radical-based reactions and exhibit a very low substrate specificity [4]. Three are the most important extracellular enzymes involved in this process, lignin peroxidases, manganese peroxidases and laccases. In general, laccases and Mnperoxidases are more widely distributed among white-rot fungi than lignin peroxidases [5].

Manganese peroxidase (MnP, EC 1.11.1.13) is one of the main oxidoreductases involved in lignin degradation [6, 7]. It is an extracellular glycosylated heme protein produced by almost all wood-colonizing white-rot fungi. MnP catalyzes the $\mathrm{H} 2 \mathrm{O} 2-$ dependent oxidation of $\mathrm{Mn} 2+$ to $\mathrm{Mn3}+$, which, in turn, acts as a non-specific oxidant that attacks phenolic lignin structures by a one-electron abstraction [8]. As MnP, lignin peroxidase (LiP, EC 1.11.1.14) is an extracellular glycoprotein able to catalyze the oxidation of a large number of aromatic compounds by $\mathrm{H} 2 \mathrm{O} 2$ [9]. The catalytic mechanism for lignin peroxidase is similar to that of other peroxidases [10,11].

Fungal laccases (LAC, EC 1.10.3.2) are multi-copper phenol oxidases that oxidize many phenolic compounds and aromatic amines using molecular oxygen as the terminal electron acceptor [12].

The degradation pattern of these enzymes has high potential for the delignification of wood and non-wood plant materials in biopulping and bioethanol production applications [13, 14].

The main aim of this study was to evaluate the ability of a fungal isolate collected for the first time from both bark and decayed wood in Uruguayan Eucalyptus plantations, to produce ligninolytic enzymes (i.e., LAC, MnP and LiP). This capacity has not been previously studied in this fungus. Bearing in mind the isolation medium of this strain, the possible stimulatory effect of Eucalyptus dunnii wood and bark on ligninolytic enzyme production was assessed.

\section{MATERIALS AND METHODS}

\section{Wood rotting fungi collection, isolation and identification}

Fruit bodies present on bark and white rotted wood from Eucalyptus globulus plantations in Palmar de Quebracho, Paysandú, Uruguay ( $31^{\circ} 55^{\prime} 12^{\prime \prime} \mathrm{S}, 57^{\circ} 42^{\prime} 48^{\prime \prime}$ W) were collected during studies of the wood rotting Basidiomycetes of Eucalyptus species from Uruguay. Specimens were hand collected and transferred to the laboratory in paper bags. For those species previously unrecorded on Eucalyptus in Uruguay $[15,16]$, were obtained isolates and voucher specimens were deposited at the herbarium of the Facultad de Ciencias, Montevideo, Uruguay (MVHC). Isolation was performed by aseptically excising small pieces of context which were plated onto Petri dishes containing $2 \%$ Malt extract agar (MEA; $2 \%$ malt extract, $1.5 \%$ agar, Difco). Pure cultures were transferred onto slants containing fresh $2 \%$ MEA and deposited in the culture collection of the Mycology Laboratory of Facultad de Ciencias, Universidad de la República. Fungal identification was performed according to micro- and macro-morphological characteristics of the fruit bodies, as described previously [16] (Martínez and Nakasone, 2010). A preliminary assessment of the possible occurrence of ligninolytic enzyme was performed on fungal cultures grown on MEA using the Stalpers' enzyme test, viz. $\alpha$-naphtol (on laccase), $1 \%$ pyrogallol $0.4 \%$ hydrogen peroxide (on peroxidase) [17]. The strain was kept at the Collection of the Biocatalysis and Biotransformation Laboratory, Facultad de Química (Montevideo, Uruguay) as DS1488.

\section{Analytical determinations of Eucalyptus dunnii wood and bark.}

Healthy E. dunnii bark and wood of 18 year-old trees were collected from the Estación Experimental Prof. Bernardo Rosengurtt, Cerro Largo, Uruguay ( $\left.32^{\circ} 21^{\prime} 57^{\prime \prime} \mathrm{S}, 54^{\circ} 26^{\prime} 25^{\prime \prime} \mathrm{W}\right)$. Samples were dried to constant weight at $100^{\circ} \mathrm{C}$, and then ground prior to analysis. Lignin determination was performed according to NREL method [18].

All samples $(30 \mathrm{~g}$ ) were sequentially extracted in a Soxhlet apparatus with $300 \mathrm{~mL}$ dichloromethane and then with $300 \mathrm{~mL}$ methanol for 25 cycles each. The solvents were rota-evaporated to dryness. The results were expressed on percent of dry wood and bark. The extracts were analyzed for their total phenolic and proanthocyanidins contents (please, see subsections 2.1 and 2.2, respectively). All determinations were performed in triplicate and the respective mean values \pm standard deviations were calculated.

\section{Total phenol content}

Total phenol content was determined by the Folin-Ciocalteu method [19, 20]. In particular, $2.5 \mathrm{~mL}$ of Folin-Ciocalteu reactive, previously diluted with water $(1: 10, \mathrm{v} / \mathrm{v})$, and $2.0 \mathrm{~mL}$ of an aqueous solution of sodium carbonate $\left(75 \mathrm{~g} \mathrm{~L}^{-1}\right)$ were added to $0.5 \mathrm{~mL}$ of a properly diluted aqueous solution of the extract. The mixture was kept for $5 \mathrm{~min}$ at $50^{\circ} \mathrm{C}$ and, after cooling, the absorbance at $760 \mathrm{~nm}$ was measured. The total phenol content was expressed as gallic acid equivalent from a calibration curve of gallic acid standard solutions $\left(15-100 \mu \mathrm{g} \mathrm{mL} \mathrm{L}^{-1}\right)$. 


\section{Proanthocyanidin content}

The proanthocyanidin determination was carried out by the vanillin- $\mathrm{HCl}$ method [21] with some modifications. In particular $1.0 \mathrm{~mL}$ of aqueous extract was mixed with $2.5 \mathrm{~mL}$ of a freshly prepared $1 \%$ vanillin solution (w/v) in methanol and $2.5 \mathrm{~mL}$ of $9 \mathrm{~mol} \mathrm{~L}^{-1} \mathrm{HCl}$ in methanol were than added. The reaction mixture was incubated for 30 min at room temperature and the

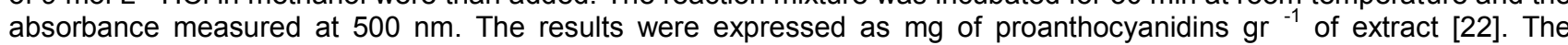
analyses were done in triplicate and the mean value calculated.

\section{Enzyme production}

The fungal strain DS-1488 was maintained on potato dextrose agar (PDA) slants at $4{ }^{\circ} \mathrm{C}$ and routinely sub-cultured every six months to maintain its viability. A preliminary approach to detect enzymes production was performed using Stalpers methodology [17].

The pre-inoculum was prepared by adding with five mycelial plugs $(1 \mathrm{~cm}$ diameter), obtained from actively growing PDA cultures, to $500 \mathrm{~mL}$ Erlenmeyer flasks containing a liquid medium (100 mL) with the following composition (\%): malt extract, 5; bacto-peptone, 1 ; E. dunnii bark/wood sawdust, 0.25 (MEPWS medium). The flasks were incubated at $28^{\circ} \mathrm{C}$ for 7 days under orbital shaking $(130 \mathrm{rpm})$. At the end of the incubation, cultures were then homogenized with the UltraTurrax T18 (IKA Labortechnik, Staufen, Germany) and used as the inoculum.

The evaluation of ligninolytic enzyme production were performed in liquid cultures under slurry conditions. In particular, the MEPWS medium was modified by adding either bark or wood $E$. dunnii sawdust at $5 \%$ (w/v) and from here onwards referred to as MMEPWS. One of the following enzyme inducers (i.e., $\mathrm{CuSO}_{4}, 80 \mathrm{ppm}, \mathrm{MnSO}_{4}, 24 \mathrm{ppm}$ ) were added to this modified basal production medium. Cultures were performed in $500 \mathrm{~mL}$ Erlenmeyer flask containing $100 \mathrm{~mL}$ MMEPWS medium either in the presence or in the absence of the above mentioned inorganic inducers and incubated at $28{ }^{\circ} \mathrm{C}$ for 16 days under orbital shaking (130 rpm). Fungal cultures, grown in parallel on malt extract peptone medium, were used as the control. Samples were collected at start and after 4, 8, 12 and 16 days incubation.

\section{Enzyme determination}

Laccase activity was assayed spectrophotometrically at $35^{\circ} \mathrm{C}$ using $2 \mathrm{mM} 2,6$-dimethoxyphenol as the substrate in $0.1 \mathrm{M}$ acetate buffer $\mathrm{pH} 4.5$ and monitoring the formation of $3,3^{\prime}, 5,5^{\prime}$ - tetramethoxy-p-diphenoquinone at $477 \mathrm{~nm}(\varepsilon=14,600$ $\mathrm{M}^{-1} \mathrm{~cm}^{-1}$ ). Total oxidase activity was determined with the same substrate solution added with $0.5 \mathrm{mM} \mathrm{MnSO} 4 \mathrm{and}_{0.2} \mathrm{mM}$ $\mathrm{H}_{2} \mathrm{O}_{2}$.

Manganese peroxidase activity was determined by subtracting laccase activity from total oxidase activity. Lignin peroxidase was measured by monitoring veratryl alcohol (VA) oxidation at $25^{\circ} \mathrm{C}$ in reaction mixtures containing $2 \mathrm{mM} V A$ in $0.1 \mathrm{M}$ sodium tartrate buffer $(\mathrm{pH} 3.0)$ and $10 \mu \mathrm{L}$ of culture filtrate in a total volume of $1 \mathrm{~mL}$. The reaction was started by adding $\mathrm{H}_{2} \mathrm{O}_{2}$ to a final concentration of $0.2 \mathrm{mM}$ and the increase in absorbance at $310 \mathrm{~nm}\left(\varepsilon=9,300 \mathrm{M}^{-1} \mathrm{~cm}^{-1}\right)$ was monitored over time.

All activities were expressed as international units (IU), defined as the amount of enzyme which produces $1 \mu$ mol of product per minute under the assay conditions.

\section{RESULTS AND DISCUSSION}

Fruit bodies of the white rot fungus studied were identified as Dichostereum sordulentum (Cooke and Massee) Boidin and Lanquetin based on macro- and microcharacteristics of the basidiocarps based on descriptions of Boidin and Lanquetin (1980) [23]. Voucher specimen was deposited at the herbaria of Facultad de Ciencias, Montevideo, Uruguay, with the number MVHC5370, being the the first record in Uruguay of this species, which had been previously collected in other South American countries and USA [23, 24, 25]. In addition, to the best of our knowledge, isolation from fruit bodies and decaying wood was performed. Oxidative tests, conducted by adding a-napthol to PDA growing cultures, showed the presence of laccase activity. Conversely, the same tests for peroxidase were negative. Although these are semiquantitative tests, the high positive laccase reaction observed and the absence of information regarding the ligninolytic enzyme production by this species prompted us to perform further experiments in liquid cultures in the presence of sawdust derived from the same medium from which $D$. sordulentum had been isolated, namely $E$. dunnil wood and bark. The combined production of $\mathrm{MnP}$ and LAC has been reported to commonly occur among selective lignindegrading white-rot fungi [6]. In the present study, regardless of the medium composition, this enzyme production pattern was evident for $D$. sordulentum DS1488. Both enzyme activities were even detected in fungal cultures performed in the malt extract and peptone control medium (LAC $0.72 \mathrm{IU} \mathrm{mL}^{-1}$ and MnP $0.21 \mathrm{IU} \mathrm{mL} \mathrm{mL}^{-1}$ on day 16) (Figures 1 and 2). In both non-supplemented and supplemented cultures, the highest MnP and LAC activities were observed at the end of the incubation. For this reason, comparisons reported in Figure 1 and 2 regard 16-day-old cultures. 


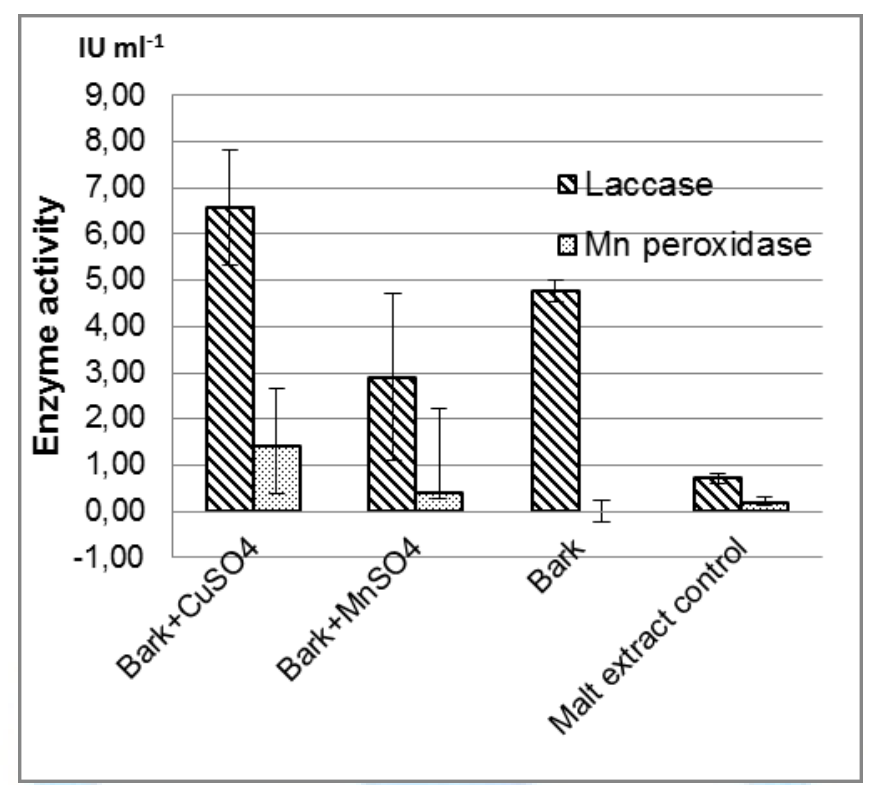

Figure 1 - LAC and MnP activity using Eucalyptus bark: Laccase and Manganese peroxidase activities in 16-day-old $D$. sordulentum culture broths from control cultures grown on the malt extract-peptone control medium and in the presence of $5 \%(w / v) ~ E$. dunnii bark sawdust alone or added with either 80
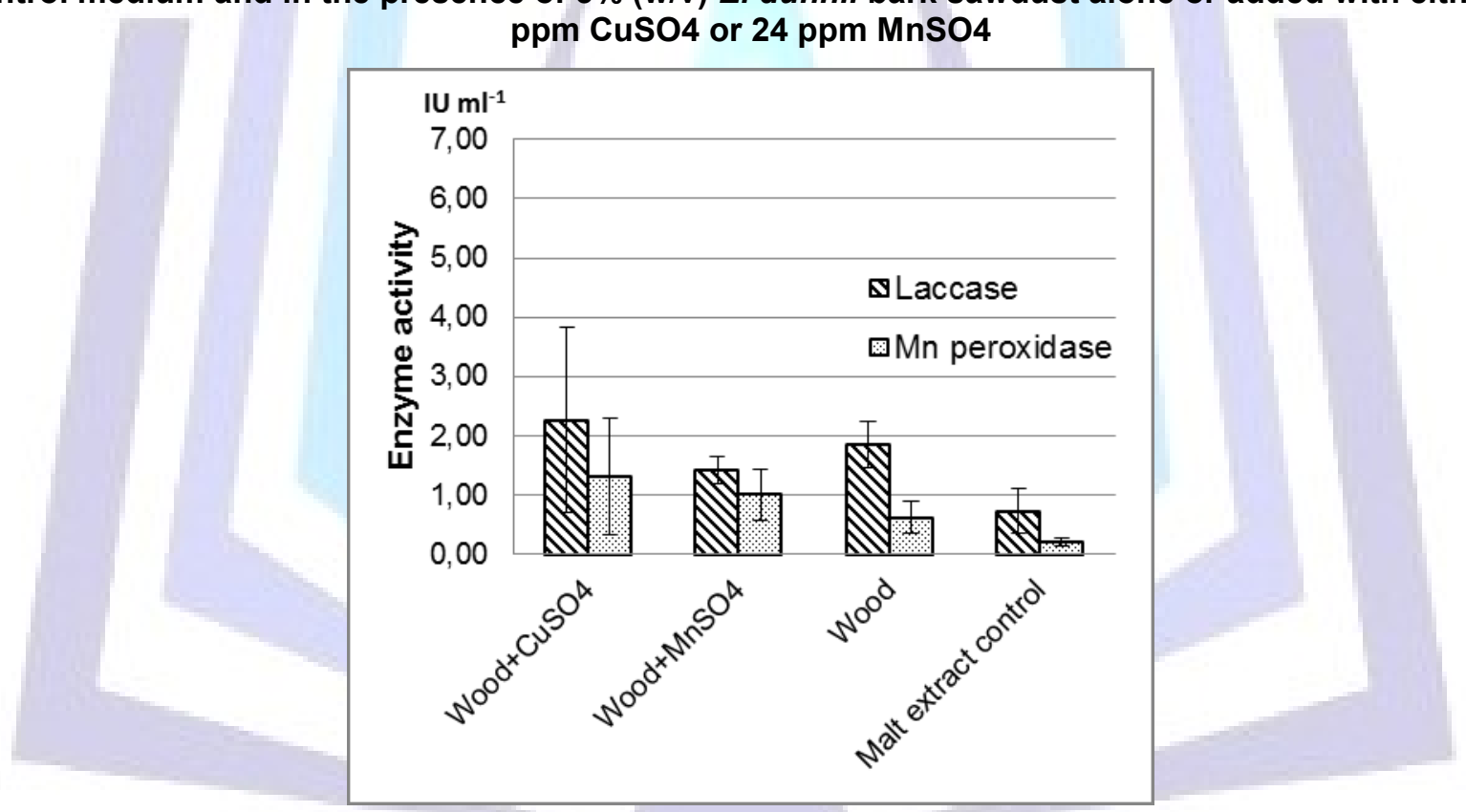

Figure 2 - LAC and MnP activity using Eucalyptus wood: Manganese peroxidase activities in 16-dayold $D$. sordulentum culture broths from control cultures grown on the malt extract-peptone control medium and in the presence of $5 \%(\mathrm{w} / \mathrm{v})$ E. dunnii wood sawdust alone or added with either $80 \mathrm{ppm}$ CuSO4 or 24 ppm MnSO4.

The addition of either bark or wood sawdust had a marked stimulatory effect on laccase production leading to a 6.6- and 2.6-fold increase, respectively, as compared to that found in control cultures. Conversely, MnP production was totally suppressed in the bark sawdust-supplemented cultures while a 3-fold increase was found in wood sawdust-supplemented ones.

In order to enhance ligninolytic enzyme production, two widely known inorganic inducers, cupric and manganous ions, were added to cultures containing either bark or sawdust. A further increase in LAC production was only observed in cultures that underwent concomitant supplementation of bark and $\mathrm{Cu}^{2+}$, reaching an activity peak of $6.56 \mathrm{IU} \mathrm{mL}^{-1}$. Conversely, in wood-supplemented cultures, LAC activity was lower in the presence of $\mathrm{Cu}^{2+}$ than in its absence $(2.27$ vs. $\left.4.78 \mathrm{IU} \mathrm{mL} \mathrm{L}^{-1}\right)$. In this respect, transcriptional activation of laccase genes by copper has been shown for several white-rot fungi $[26,27,28,29,30]$ and the presence of putative metal response elements in the promoter of $P$. ostreatus laccase genes has been shown [31]. 
The stimulatory effect of $\mathrm{Mn}^{2+}$ on $\mathrm{MnP}$ production is well established [32,33]. In the present study, a MnP activity of 0.42 IU $\mathrm{mL}^{-1}$ was observed in cultures that underwent concomitant addition of bark and $\mathrm{Mn}^{2+}$. Thus, the presence of $\mathrm{Mn}^{2+}$ appeared to counteract the suppression of this activity that had been observed in cultures supplemented with bark alone. In wood-supplemented cultures, instead, the concomitant presence of $\mathrm{Mn}^{2+}$ led to a moderate increase from $0.62 \mathrm{U}$ to 1.0 IU $\mathrm{mL}^{-1}$ with respect to cultures supplemented with wood sawdust alone. $\mathrm{Mn}^{2+}$ exerted a depressive effect on laccase production in cultures supplemented with either wood or bark with respect to cultures supplemented with these additives alone (2.91 vs. $4.78 \mathrm{IU} \mathrm{mL}^{-1}$, respectively, and 1.42 vs. $1.85 \mathrm{IU} \mathrm{mL}^{-1}$, respectively).

In summary, best results were obtained in cultures undergoing concomitant bark and $\mathrm{Cu}^{2+}$ addition, where laccase and $\mathrm{MnP}$ activities were 9 and 7 times higher than those found in the control medium. Bark was more effective than wood in stimulating laccase production. Table 1 shows that the methanol extracts from $E$. dunnii wood and bark had very similar total phenolic contents (321.4 vs. $398.4 \mathrm{mg} \mathrm{GAE} \mathrm{g}^{-1}$ d.w.) while they differed in their respective proanthocyanidins contents by two orders of magnitude ( 3.4 vs. $321.4 \mathrm{mg} \mathrm{g}^{-1} \mathrm{dw}$ ). In this respect, this is in line with Pinto and collaborators suggesting that the most significant differences between Eucalyptus bark and wood stemmed from their contents in polar compounds [34]. It has been reported that the main polar extractives in the Eucalyptus bark are tannins, polyphenolic compounds and flavonoids [35]. Results of the present study suggest that $E$. dunnii bark sawdust might be a valuable stimulator of laccase production in liquid cultures.

Table 1- Soluble and Insoluble lignin, Total phenol and Proanthocyanidins content of Eucalyptus dunnii bark and wood

\begin{tabular}{|c|c|c|c|c|}
\hline $\begin{array}{c}\text { E. dunni } \\
\text { sawdust } \\
\text { from }\end{array}$ & $\begin{array}{c}\text { Insoluble lignin } \\
(\%)\end{array}$ & $\begin{array}{c}\text { Soluble lignin } \\
(\%)\end{array}$ & $\begin{array}{c}\text { Total phenol } \\
\left(\mathrm{mg} \mathrm{GA}_{\mathrm{g}}{ }^{-1}\right. \\
\text { d.w. })\end{array}$ & $\begin{array}{c}\text { Proanthocyanidins } \\
\left(\mathrm{mg} \mathrm{g}^{-1} \text { d.w. }\right)\end{array}$ \\
\hline Bark & $16,40 \pm 0,21$ & $3,89 \pm 0,03$ & $398,2 \pm 9,3$ & $229,1 \pm 5,3$ \\
\hline Wood & $20,0 \pm 0,55$ & $2,53 \pm 0,05$ & $321,4 \pm 7,5$ & $3,4 \pm 0,2$ \\
\hline
\end{tabular}

†GA: gallic acid

\section{CONCLUSION}

A species of the white-rot Basidiomycete present in Eucalyptus plantations and previously not recorded in Uruguay was isolated and identified as $D$. sordulentum $[15,16]$. To the best of our knowledge, pure cultures obtained from fruit bodies of of this species was carried on for regarding the $D$. sordulentum ability for producing extracellular ligninolytic enzymes.

The results showed that this species produces both Laccase and Manganese peroxidase with the former enzyme being predominant; under the tested conditions, no Lignin peroxidase activity was observed.

The better efficacy of bark in stimulating LAC production than wood might stem from its higher proanthocyanidins content.

\section{ACKNOWLEDGMENTS}

This work was financially supported by Agencia Nacional de Investigación e Innovación (ANII) Project FSE_1_2011_1_6468, Comisión Sectorial de Investigación Científica (CSIC) and PEDECIBA Química.

The authors also would like to thank the Bilateral agreement between Università degli Studi della Tuscia and Universidad de la República.

\section{REFERENCES}

[1] MGAP. 2013. DIEA. Anuario Estadistico Agropecuario 2013.

[2] Santos, S.A.O., Freire, C.S.R., Domingues, M.R.M., Silvestre A.J.D. and Neto CP. 2011. Characterization of Phenolic Components in Polar Extracts of Eucalyptus globulus Labill. Bark by High-Performance Liquid Chromatography- Mass Spectrometry. J. Agric. Food. Chem. 59,9386-9393.

[3] Santos, S.A.O., Villaverde, J.J., Freire, C.S.R., Domingues, M.R.M., Neto, C.P. and Silvestre, A.J.D. 2012. Phenolic composition and antioxidant activity of Eucalyptus grandis, E. urograndis (E. grandis $\times E$. urophylla) and E. maidenii bark extracts. Ind. Crops Prod. 39, 120-127.

[4] Janusz, G., Kucharzyk, K.H., Pawlik, A., Staszczak, M. and Paszczynski, A.J. 2013. Fungal laccase, manganese peroxidase and lignin peroxidase: Gene expression and regulation. Enzyme Microb. Tech. 52, 1-12.

[5] Pelaez, F., Martinez, M.J. and Martinez,. AT. 1995. Screening of 68 species of basidiomycetes for enzymes involved in lignin degradation. Mycol. Res. 99, 37-42.

[6] Hatakka, A. 1994. Lignin-modifying enzymes from selected white-rot fungi: production and role from in lignin degradation. FEMS Microbiol. Rev. 13, 125-135.

[7] Kirk, T.K. and Farrell, R.L. 1987. Enzimatic "combustion": the microbial degradation of lignin. Annu. Rev. Microbiol. 41, 465-505. 
[8] Steffen, K.T., Hofrichter, M. andHatakka, A. 2002. Purification and characterization of manganese peroxidases from the litter-decomposing basidiomycetes Agrocybe praecox and Stropharia coronilla. Enzyme Microb. Technol. 30,550555.

[9] Tien, M. and Tu, C.D. 1987. Cloning and sequencing of a cDNA for a ligninase from Phanerochaete chrysosporium. Nature 326, 520-523.

[10] Kirk, T.K., Croan, S., Tien, M., Murtagh, K.E. and Farrell, R.L. 1986. Production of multiple ligninases by Phanerochaete chrysosporium: effect of selected growth conditions and use of a mutant strain. Enzyme Microb. Technol. 8, 27- 32.

[11] Dunford, H.B. and Stillman, J.S. 1976. On the function and mechanism of action of peroxidases. Coordin. Chem. Rev. 19, 187-251.

[12] Giardina, P., Faraco, V., Pezzella, C., Piscitelli, A., Vanhulle, S. and Sannia, G. 2010. Laccases: a never-ending story. Cell. Mol. Life Sci. 67, 369-385.

[13] Akhtar, M., Attridge, M.C., Myers, G.C. and Blanchette, R.A. 1993. Biomechanical Pulping of Loblolly Pine Chips with Selected White-Rot Fungi. Holzforschung 47, 36-40.

[14] Salvachua, D., Prieto, A., Lopez-Abelairas, M., Lu-Chau, T., Martinez, A.T. and Martinez, M.J. 2011. Fungal pretreatment: An alternative in secondgeneration ethanol from wheat straw. Bioresour. Technol. 102, 7500-7506.

[15] Bettucci, L., Speranza, M., Piaggio, M., Sineris, F. and Breccia, J.B. 1998. Degradation of Eucalyptus globulus and Eucalyptus grandis by several white rot fungi isolated in South America. Mater. Organismen. 32, 227-233.

[16] Martinez, S. and Nakasone, K. 2010. New records and checklist of corticioid Basidiomycota from Uruguay. Mycotaxon 114, 281-284.

[17] Stalpers, J.A. 1978. Identification of wood rotting Aphyllophorales in pure Culture. Stud. Mycol. 16, 1-243.

[18] Sluiter, A., Hames, B., Ruiz, R., Scarlata, C., Sluiter, J., Templeton, J. and Crocker, D. 2008. Determination of Structural Carbohydrates and Lignin in Biomass. Laboratory Analytical Procedure. National Renewable Energy Laboratory.

[19] Singleton, V.L. and Rossi, J.A.J. 1965. Colorimetry of Total Phenolics with Phosphomolybdic-Phosphotungstic Acid Reagents. Am. J. Enol. Vitic. 16, 144-158.

[20] Vazquez, G., Fontenla, E., Santos, J., Freire, M.S., Gonzalez-Alvarez, J., Antorrena, G. 2008. Antioxidant activity and phenolic content of chestnut (Castanea sativa) shell and eucalyptus (Eucalyptus globulus) bark extracts. Ind. Crops Prod. 28, 279-285.

[21] Nakamura, Y., Tsuji, S. and Tonogai, Y. 2003. Analysis of proanthocyanidins in grape seed extracts, health foods and grape seed oils. J. Health Sci. 49, 45-54.

[22] Cadahia, E., Conde, E., Fernandez De Simon, B. and Garcia-Vallejo, M.C. 1997. Tannin composition of Eucalyptus camaldulensis, E. globulus and E. rudis - Part II. Bark. Holzforschung 51,125-129.

[23] Boidin, J., and Lanquetin, P. 1980. Contribution a l'etude du genre Dichostereum Pilat (Basidiomycetes, Lachnocladiaceae). Bull. Soc. Mycol. France. 96, 381-406.

[24] Abrahao, M.C., de Mello, G.A.and Ramos, B.V.L. 2012. Xylophilous Agaricomycetes (Basidiomycota) of the Brazilian Cerrado. Check List 8:1102-1116.

[25] Nakasone, K.K. 1990. Cultural studies and identification of wood-inhabiting Corticiaceae and selected Hymenomycetes from North America. Mycol. Mem. 15, 1-412.

[26] Collins, P.J. and Dobson, A.D.W. 1997. Regulation of laccase gene transcription in Trametes versicolor. Appl. Environ. Microbiol. 63, 3444-3450.

[27] Karahanian, E., Corsini, G., Lobos, S. and Vicuna, R. 1998. Structure and expression of a laccase gene from the ligninolytic basidiomycete Ceriporiopsis subvermispora. Biochim Biophys Acta. 1443, 65-74.

[28] Palmieri, G., Giardina, P., Bianco, C., Fontanella, B. and Sannia, G. 2000. Copper induction of laccase isoenzymes in the ligninolytic fungus Pleurotus ostreatus. Appl. Environ. Microb. 66, 920-924.

[29] Galhaup, C., Wagner, H., Hinterstoisser, B. and Haltrich, D. 2002. Increased production of laccase by the wooddegrading basidiomycete Trametes pubescens. Enzyme Microb. Technol. 30, 529-536.

[30] Soden, D.M.andDobson, A.D.W. 2003. The use of amplified flanking region- PCR in the isolation of laccase promoter sequences from the edible fungus Pleurotus sajor-caju. J. Appl. Microbiol. 95, 553-562.

[31] Faraco, V., Giardina, P. and Sannia, G. 2003. Metal-responsive elements in Pleurotus ostreatus laccase gene promoters. Microbiology 149, 2155-2162.

[32] Gold, M.H., Youngs, H.L. and Gelpke, M.D. 2000. Manganese peroxidase. Met. lons Biol. Syst. 37, 559-586. 
[33] Hilden, K., Martinez, A.T, Hatakka, A. and Lundell, T. 2005. The two manganese peroxidases Pr-MnP2 and Pr-MnP3 of Phlebia radiata, a lignindegrading basidiomycete, are phylogenetically and structurally divergent. Fungal Genet. Biol. 42, 403-419.

[34] Pinto, P.C.R., Sousa, G., Crispim, F., Silvestre, A.J.D. and Neto, C.P. 2013. Eucalyptus globulus Bark as Source of Tannin Extracts for Application in Leather industry. ACS Sustainable Chem. Eng. 1, 950-955.

[35] Yadav, K.R., Sharma, R.K. and Kothari,R.M. 2002. Bioconversion of Eucalyptus bark waste into soil conditioner. Bioresour. Technol. 81, 163-165. 